\title{
Fabrication of Semi-Transparent Photovoltaic Cell by a Cost-Effective Technique
}

\author{
K.N. NITHYAYINI and SHEELA K. RAMASESHA \\ Semi-transparent inorganic thin film PV cells have been fabricated using n-type (CdS) and \\ p-type (CdTe) semiconductors. Large area devices which can be used as windows and skylights \\ in buildings can be fabricated using cost effective solution processes. The device structure is \\ Glass/TCO/CdTe/CdS/TCO. Chemically stable $\mathrm{CdS}$ and $\mathrm{CdTe}$ layers are deposited at \\ temperatures $353 \mathrm{~K}$ to $373 \mathrm{~K}\left(80{ }^{\circ} \mathrm{C}\right.$ to $\left.100{ }^{\circ} \mathrm{C}\right)$ under controlled $\mathrm{pH}$. The $\mathrm{CdCl}_{2}$ activation is \\ carried out followed by air annealing. The p-n junction is formed by sintering the device at \\ $673 \mathrm{~K}$ to $723 \mathrm{~K}\left(400{ }^{\circ} \mathrm{C}\right.$ to $\left.450{ }^{\circ} \mathrm{C}\right)$. The characterization of cells is carried out using XRD, \\ SEM, AFM, and UV-Visible spectroscopy. The thickness of the cell is $\sim 600 \mathrm{~nm}$. The band gap \\ values are $2.40 \mathrm{eV}$ for $\mathrm{CdS}$ and $1.36 \mathrm{eV}$ for CdTe with transmittance of about 70 pct in the \\ visible region. Under $1.5 \mathrm{AM}$ solar spectrum, $V_{\mathrm{oc}}$, and $I_{\mathrm{sc}}$ of the initial device are $3.56 \mathrm{e}-01 \mathrm{~V}$ \\ and $6.20 \mathrm{e}-04 \mathrm{~A}$, respectively.
}

DOI: $10.1007 / \mathrm{s} 40553-015-0053-\mathrm{x}$

(C) ASM International (ASM) and The Minerals, Metals \& Materials Society (TMS) 2015

\section{INTRODUCTION}

Climate change and global warming have been major challenges of the world, mainly due to the increase in carbon dioxide $\left(\mathrm{CO}_{2}\right)$ levels. The prime sources of energy being used presently are the fossil fuels, which include coal, natural gas, and oil. The overall amount of fossil fuels consumed for energy generation in 2012 was $10,848.9$ million tons, which increased to $11,032.2$ million tons in $2013 .^{[1]}$ This increase in consumption of fossil fuels led to an increase in $\mathrm{CO}_{2}$ emission from 35.6 billion tons to 36.3 billion tons. ${ }^{[2]}$ One of the effective ways of reducing $\mathrm{CO}_{2}$ emission is by supplementing fossil fuels by renewable energy sources. Innovations, research, and development in renewable energy resources and associated energy harnessing systems is of significance in modern science. Among all the renewable energy sources, solar energy is identified as the most abundantly available and viable energy source. In this connection, attempts are being made to convert every possible surface to a photovoltaic (PV) surface in order to generate electricity. The surfaces presently being used for natural illumination in buildings such as windows, ventilators, and skylight are being converted to PV surfaces by suitable modifications in the materials. ${ }^{[3]}$ This would not only be an effective solution to reduce the consumption of fossil fuels but also would be a catalyst in reducing the price of PV systems. This paper deals with a process for the

K.N. NITHYAYINI, Senior Research Fellow and SHEELA K. RAMASESHA, Visiting Research Scientist, are with the Divecha Centre for Climate Change, Indian Institute of Science, Bangalore 560012, India. Contact e-mail: sheela@caos.iisc.ernet.in

Manuscript submitted June 10, 2015.

Article published online August 27, 2015 fabrication of semi-transparent semiconductor based $\mathrm{PV}$, which can be used as window panes and skylights.

Inorganic PV cell, in general, consists of substrate coated with transparent conductive oxide (TCO), window layer (n type), absorber layer (p type), and metal contact layer. TCOs are highly transparent (generally n-type semiconductors) with good electrical conductivity. A window layer forms junction with the absorber layer and allows maximum amount of light to the junction region. Cadmium Telluride (CdTe) is a p-type II-VI group semiconductor. It is a stable absorber with a direct band gap of $1.45 \mathrm{eV}$ and high optical absorption coefficients. Cadmium sulfide (CdS) is a photosensitive n-type semiconductor. It is also a stable compound with a direct band gap of $2.42 \mathrm{eV}$. The combination of these two semiconductor materials results in $\mathrm{CdTe} / \mathrm{CdS} \mathrm{p}-\mathrm{n}$ junction. At the p-n junction, during the activation step, intermixing of CdTe and $\mathrm{CdS}$ takes place, resulting in the formation of $\mathrm{CdTe}_{x} \mathrm{~S}_{1-x}$ region. ${ }^{[4]}$ Polycrystalline $\mathrm{CdTe} / \mathrm{CdS}$ thin film solar cell is one of the highly focused areas of research. Many techniques such as vacuum evaporation, sputtering, thermal evaporation, electro deposition, metal vapor organic deposition, epitaxial growth, spin coating, closed spaced sublimation, and spray pyrolysis are reported to grow the CdTe thin films. ${ }^{[5-13]}$ To fabricate a solar cell, although there are different deposition techniques, chemical bath deposition (CBD) is suitable to get low-cost, large-area, and uniform thin films. CdTe thin films by CBD technique have been achieved by few researchers. ${ }^{[14]} \mathrm{CdS}$ as window layer in high-efficiency thin-film solar cells is well established. ${ }^{[15-19]}$ The film growth and device properties are dependent on the device structure. The most effective parameter that affects the transparency and cost of the cell is the film thickness. In this work, we have developed a cost-effective, semi-transparent inorganic thin film solar cell with substrate configuration for future application. 


\section{EXPERIMENTAL DETAILS}

Indium-doped tin oxides (coated on glass) with a sheet resistance of 4 to $8 \Omega$ /square from Delta Technologies Limited were used as substrates. Prior to the deposition process, the indium tin oxide-coated glass substrates were cleaned in acetone, hot distilled water, ethanolamine solution, and ethanol with ultra-sonication for 10 minutes in each solvent. The ultra-sonication was followed by rinsing in de-ionized water and dry air blowing.

\section{A. CdTe Thin Film}

Cadmium Telluride thin films were deposited by CBD process. The procedure has been described in detail elsewhere. The bath solution was cadmium acetate $(1.11 \mathrm{M})$, tellurium dioxide $(0.07 \mathrm{M}$ dissolved in $12 \mathrm{ml}$ of conc. $\left.\mathrm{H}_{2} \mathrm{SO}_{4}\right), 30 \mathrm{ml}$ of TEA, hydrazine hydrate, and $100 \mathrm{ml}$ of ammonia (25 pct). The $\mathrm{pH}$ of the bath solution was maintained at 13 and the deposition was carried out for 60 minutes at $365 \mathrm{~K}\left(92^{\circ} \mathrm{C}\right)$. Deposition for about 60 minutes produced a $\mathrm{CdTe}$ thin film of $100 \mathrm{~nm}$ thick and is of dark ash color. After CdTe deposition, the films were treated with wet cadmium chloride $\left(\mathrm{CdCl}_{2}\right)$ followed by air annealing at $623 \mathrm{~K}$ $\left(350^{\circ} \mathrm{C}\right)$. The procedure has been described in detail elsewhere. ${ }^{[20]}$ Similar procedure was repeated to get multiple layers of CdTe thin films. Initially, $\mathrm{Cd}^{2+}$ ions form a complex with triethanolamine which is stable in highly basic medium (100 $\mathrm{ml}$ ammonia). Hydrazine hydrate reduces tellurium, and at high temperature, a cadmium-TEA complex gets dissociated resulting in the association of $\mathrm{Cd}^{2+}$ and $\mathrm{Te}^{2-}$ ions forming CdTe.

Cadmium ions form a stable complex with triethanolamine in the presence of ammonia:

$$
\underset{\text { Cadmium ion }}{\mathrm{Cd}^{2+}}+\mathrm{TEA}^{\text {ammonia }} \underset{\text { Cadmium-TEA Complex }}{\left[\mathrm{Cd}(\mathrm{TEA})_{n}\right]^{2+}}
$$

Hydrazine hydrate reduces $\mathrm{TeO}_{2}$ to $\mathrm{Te}^{2-}$,

$$
\underset{\mathrm{TeO}_{2}}{\mathrm{TeO}_{2}} \stackrel{\text { hydrazine hydrate }}{\rightarrow} \mathrm{Te}^{2-}
$$

At higher temperature, cadmium-TEA complex dissociates and both $\mathrm{Cd}^{2+}$ and $\mathrm{Te}^{2-}$ ions associate, resulting in the formation of cadmium telluride:

$$
\left[\mathrm{Cd}(\mathrm{TEA})_{n}\right]^{2+}+\mathrm{Te}^{2+} \rightarrow \underset{\text { Cadmium telluride }}{\mathrm{CdTe}}+n(\mathrm{TEA})
$$

\section{B. CdS Thin Film}

Cadmium Sulfide thin films were also deposited by chemical bath deposition technique at $353 \mathrm{~K}\left(80^{\circ} \mathrm{C}\right)$ from stirred bath solution. The procedure for $\mathrm{CdS}$ deposition is well optimized by many researchers. ${ }^{[21]} \mathrm{An}$ aqueous solution of cadmium acetate $(0.002 \mathrm{M})$, thiourea $(0.005 \mathrm{M})$, and ammonium acetate $(0.02 \mathrm{M})$ was prepared. Ammonia solution $(20 \mathrm{ml})$ as a complexing agent was added later to adjust the $\mathrm{pH}$ of the bath to 10. Bath solution was mixed thoroughly under stirring to get clear homogeneous solution. Then the solution was placed in oil bath. Once the bath solution attains a constant temperature of $353 \mathrm{~K}\left(80{ }^{\circ} \mathrm{C}\right)$, substrates were introduced. $\mathrm{CdS}$ thin films were coated on $\mathrm{CdCl}_{2}$ treated CdTe layers. The films were allowed to deposit for 45 to 60 minutes to get 80 to $100 \mathrm{~nm}$ of thickness. The deposited thin films were highly adhesive, uniform, and light yellowish.

Cadmium acetate with ammonium acetate, in the presence of ammonia, forms a complex.

Tetra-ammonium cadmium(II) complex:

$$
\underset{\text { Cadmium acetate }}{\mathrm{Cd}\left(\mathrm{CH}_{3} \mathrm{COOH}\right)_{2}}+4 \mathrm{NH}_{3} \rightarrow \underset{\text { tetraammonium cadmium(II) complex }}{\left[\mathrm{Cd}(\mathrm{NH})_{3}\right]^{2+}+2 \mathrm{CH}_{3} \mathrm{CHOO}}
$$

The tetra-ammonium cadmium (II) complex undergoes decomplexation, resulting in the formation of cadmium ions:

$$
\left[\mathrm{Cd}\left(\mathrm{NH}_{3}\right)_{4}\right]^{2+} \rightarrow \mathrm{Cd}^{2+}+4 \mathrm{NH}_{3}
$$

Hydrolysis of thiourea in basic medium results in sulfide ions:

$$
\mathrm{SC}\left(\mathrm{NH}_{2}\right)_{2}+2 \mathrm{OH}^{-} \rightarrow \mathrm{S}^{2-}+\mathrm{CN}_{2} \mathrm{H}_{2}+2 \mathrm{H}_{2} \mathrm{O}
$$

When the ionic products of both $\mathrm{Cd}^{2+}$ and $\mathrm{S}^{2-}$ ions become greater than the solubility product of cadmium sulfide, it precipitates at the surface of the substrate, leading to thin film.

$$
\mathrm{Cd}^{2+}+\mathrm{S}^{2-} \rightarrow \underset{\text { Cadmium sulphide }}{\mathrm{CdS}}
$$

\section{Cell Fabrication}

The $\mathrm{p}-\mathrm{CdTe} / \mathrm{n}-\mathrm{CdS}$ heterojunction thin-film solar cell was fabricated by annealing in air at $723 \mathrm{~K}\left(450{ }^{\circ} \mathrm{C}\right)$ for 1 minute. The surface of CdS film was washed and ultrasonically cleaned in de-ionized water for 5 minutes prior to electrode deposition. Figure 1 shows the photograph of the device at different stages. The metal contact was 70 to $100 \mathrm{~nm}$ of aluminium. Then silver epoxy contacts were applied to both aluminium and ITO electrodes. Diffraction spectra were recorded using the Philips XRD X'PERT PRO diffractometer $(\mathrm{Cu}-\mathrm{K} \alpha$ radiation with $\lambda=1.5418 \AA$ ) under continuous $2 \theta$ scan. Perkin-Elmer Lamda 35 UV-Visible spectrophotometer was used to record UV-Visible absorption spectra and the transmittance in 300 to 1100 wavelength range. Atomic force microscopic studies were carried out using Dimension ICON with Scan-Asyst 2 machine. Scanning electron microscopic studies were carried out on as deposited and thermally treated thin films using Field Emission Scanning Electron Microscope (Karl Zeiss). The electrical characterization was carried out using Tracer-2 solar simulator under $1000 \mathrm{~W} / \mathrm{m}^{2}$ (1 SUN) incident power and 1.5 AM solar light spectrum. The measurement system was calibrated with 9 pct efficient silicon solar cell. 


\section{RESULTS AND DISCUSSION}

\section{A. Structural Studies}

The XRD pattern of the ITO substrate and the $\mathrm{p}-\mathrm{CdTe} / \mathrm{n}-\mathrm{CdS}$ thin-film solar cell are shown in Figure 2. The XRD pattern reveals the presence of CdTe, CdS, and ITO. The well-defined diffraction peaks are at 2 theta of 23.60, $26.2428 .29,30.04$, and 34.94. The peak at 23.60 corresponds to the cubic phase of CdTe at (111) plane. (JCPDS file No. 65-1082). The peaks at 26.24 (111) and 28.29 (101) correspond to the cubic and hexagonal phases, respectively, of CdS. (JCPDS file No. 75-0581, 75-1545). The sharp diffraction peaks indicate the formation of well crystallized film. The ITO peaks in the diffractogram were compared with standard values of JCPDF file No. 39-1058). The crystallite size of the film was calculated using the Scherrer formula

$$
D=\frac{K \lambda}{\beta \cos \theta},
$$

where $K$ is Scherrer's constant, $\lambda$ is the wavelength of $\mathrm{X}$-ray used, $\beta$ is full-width at half maximum, and $\theta$ is Bragg angle. The crystalline sizes in CdTe and CdS films are of the order $150 \mathrm{~nm}(\mathrm{CdS})$ and $250 \mathrm{~nm}(\mathrm{CdTe})$ and are in good agreement with the reported values. ${ }^{[22,23]}$
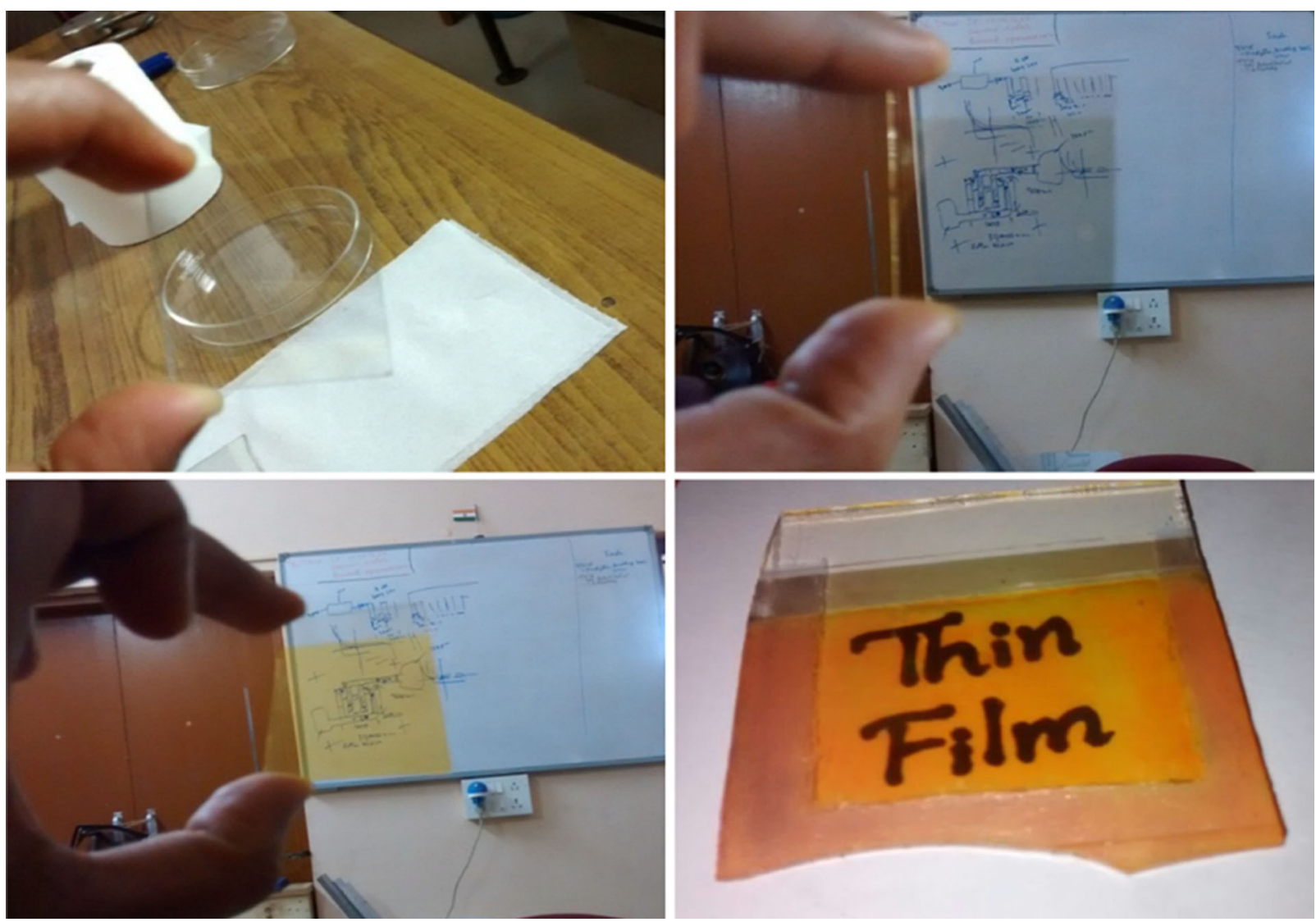

The SEM micrographs of thin films of CdTe and CdS deposited on ITO substrates are shown in Figure 3. Thin films, before and after thermal treatment at $623 \mathrm{~K}$ $\left(350{ }^{\circ} \mathrm{C}\right)$ for 10 minutes in air, are shown in Figures 3(a) through (d). The images show the substrate with as

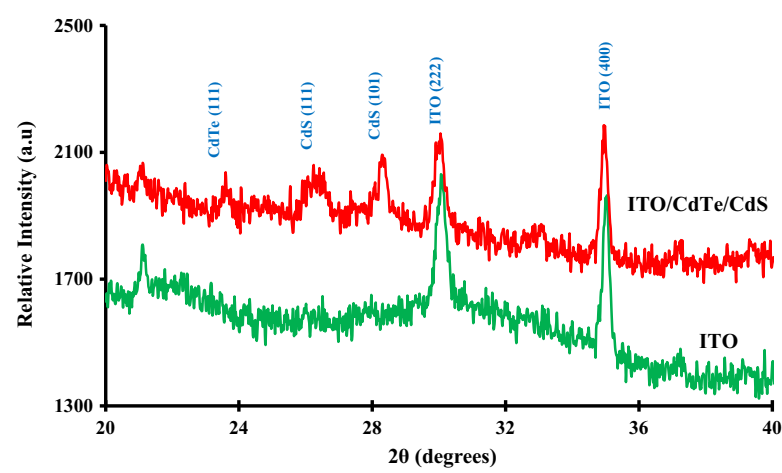

Fig. 2-X-ray diffractograms of the ITO Substrate and CELL (ITO $\mathrm{CdTe} / \mathrm{CdS})$ annealed at $723 \mathrm{~K}\left(450{ }^{\circ} \mathrm{C}\right)$ in air.
1. Scanning electron micrographs

Fig. 1-Photographic images of transparent thin film and a PV. 


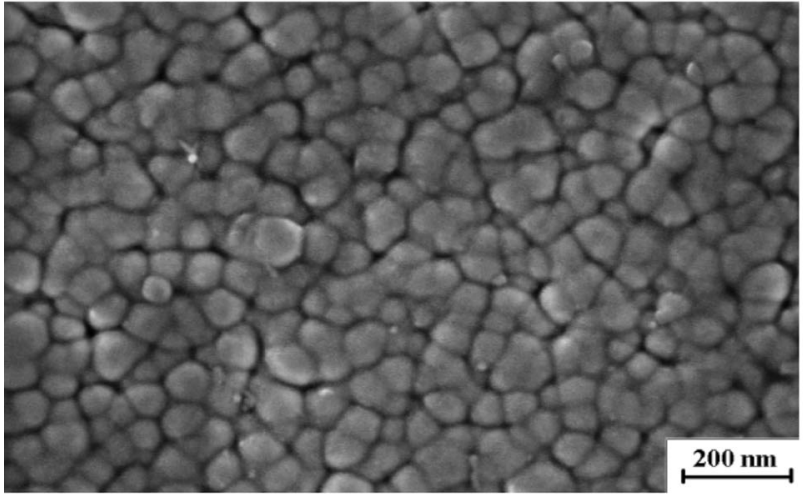

(a)

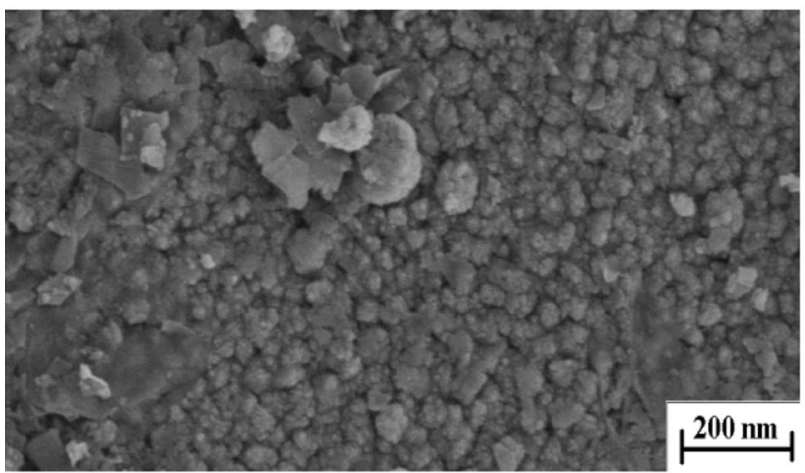

(c)

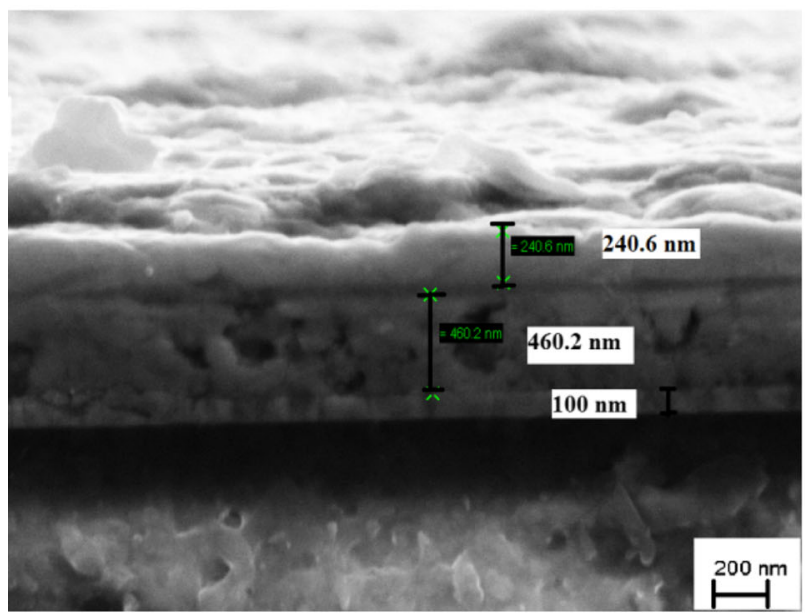

(e)

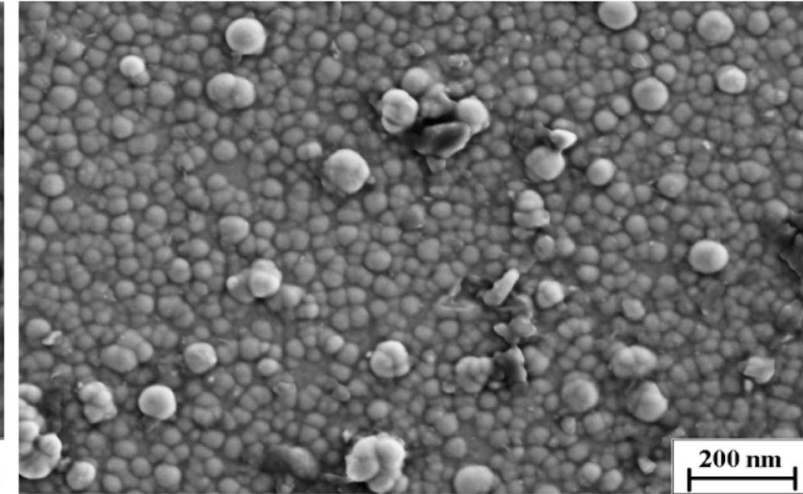

(b)

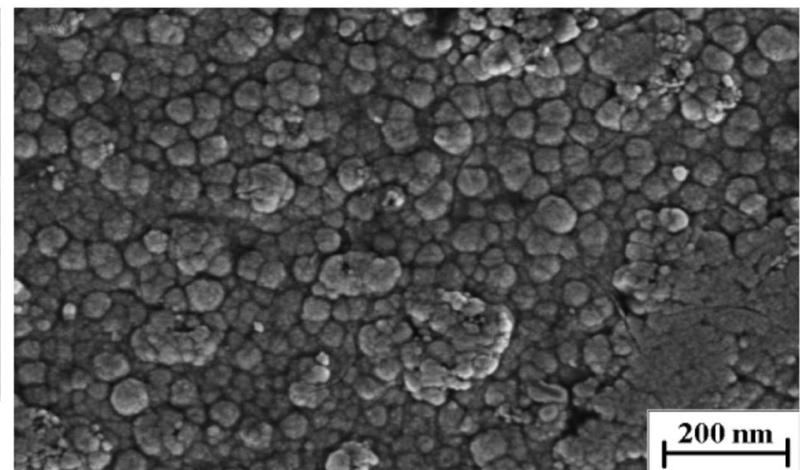

(d)

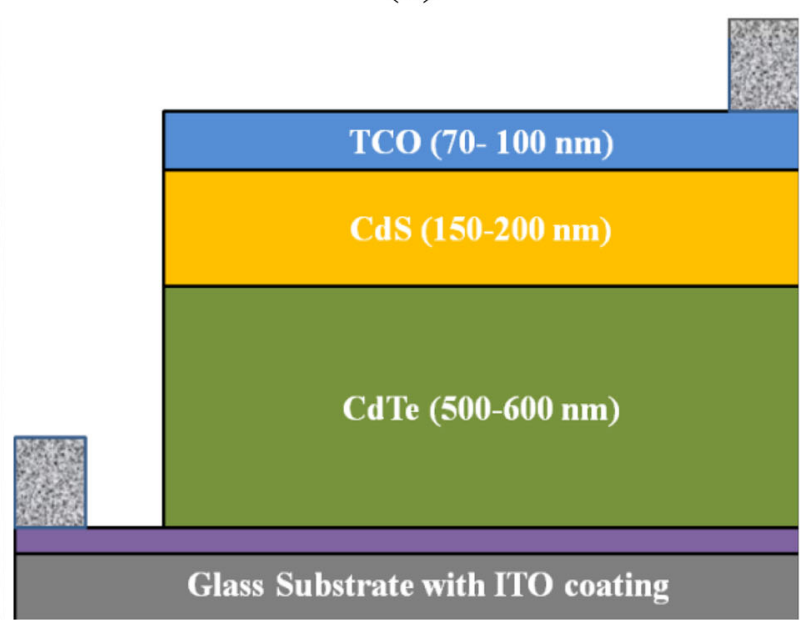

(f)

Fig. 3 - Scanning electron micrographs of (a) CdTe (as deposited), (b) CdTe annealed at $623 \mathrm{~K}\left(350{ }^{\circ} \mathrm{C}\right),(c) \mathrm{CdS}($ as deposited), $(d) \mathrm{CdS}$ annealed at $623 \mathrm{~K}\left(350{ }^{\circ} \mathrm{C}\right),(e)$ Cross sectional image of ITO/CdTe/CdS thin film, and $(f)$ substrate configuration of the device.

deposited $\mathrm{CdTe} / \mathrm{CdS}$ thin films were uniform with no porosity. After thermal treatment, the substrate was well covered with densely packed crystallite-fused each other resulting in the large size spherical polycrystalline grains. The average size of the grains was found to be 15 to $150 \mathrm{~nm}$ (CdS) and 200 to $270 \mathrm{~nm}$ (CdTe). Figure 3(e) depicts the cross-sectional image of the device and it confirms the film thickness of ITO $(100 \mathrm{~nm}), \mathrm{CdTe}$ (5 layers) (450 to $500 \mathrm{~nm})$, and CdS of $200 \mathrm{~nm}$ (2 layers). Hence, the total thickness of the device was found to be around $600 \mathrm{~nm}$. Figure 3(f) shows the schematic diagram of substrate configuration of the device.

\section{Atomic force microscopy}

Morphological characterisation of ITO, CdTe, and CdS thin film were done by AFM analysis. Figures 4(a) through (d) shows the three-dimensional surface structure of every layer of the CELL (ITO, CdTe, and CdS). The surface roughness was evaluated by root-meansquare (RMS) values. Cadmium chloride activation resulted in the smoothening of the surface. The surface 


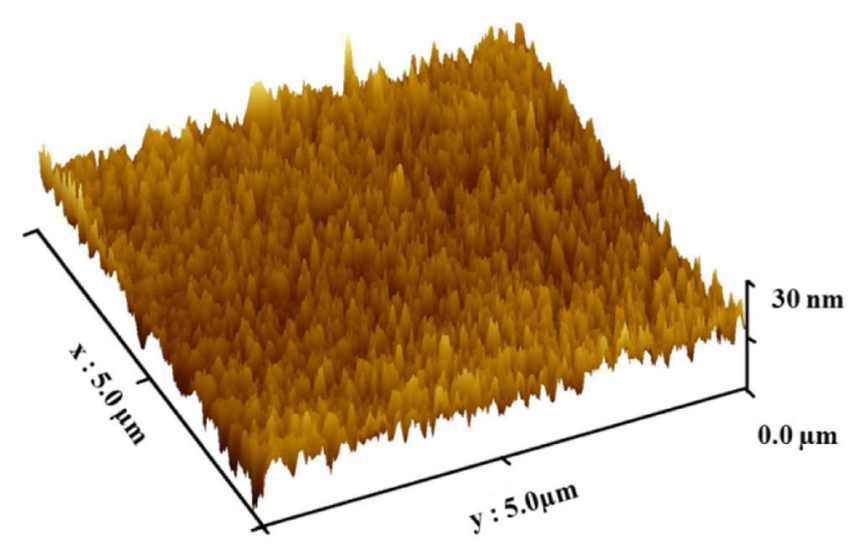

(a)

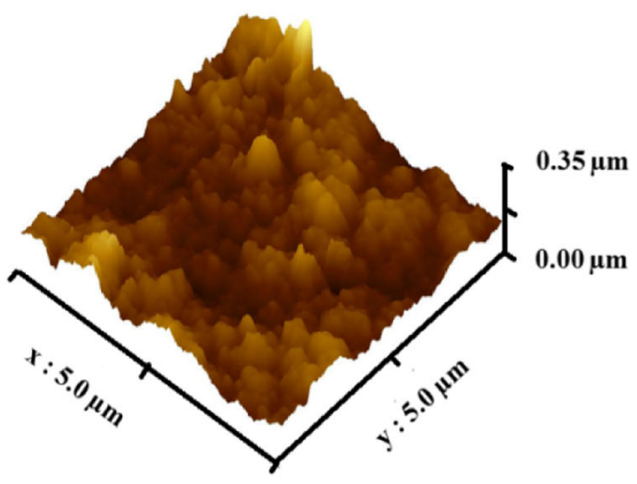

(c)

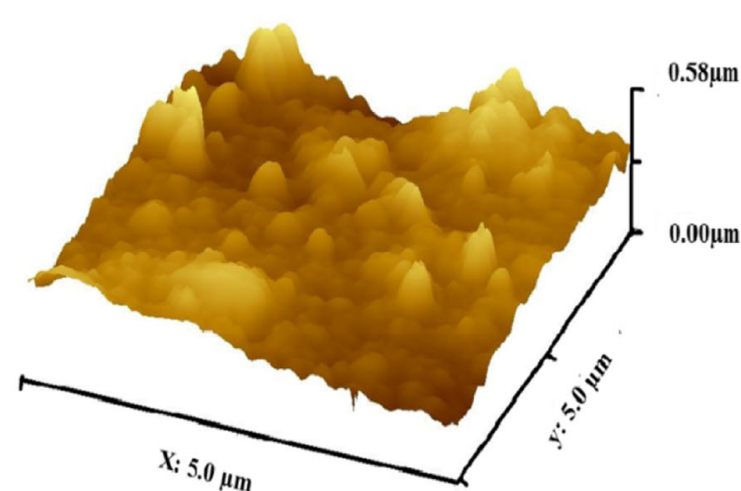

(b)

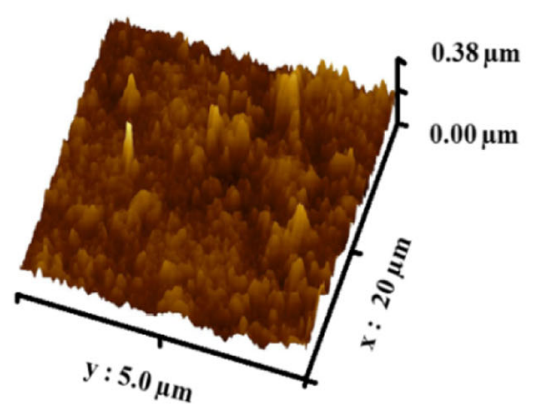

(d)

Fig. 4-Three dimensional AFM images of (a) ITO, (b) $\mathrm{CdCl}_{2}$ activated $\mathrm{CdS},(c) \mathrm{CdCl}_{2}$ activated $\mathrm{CdTe}$, and $(d) \mathrm{ITO} / \mathrm{CdTe} / \mathrm{CdS}\left(\mathrm{CdCl} l_{2}\right.$ activated).

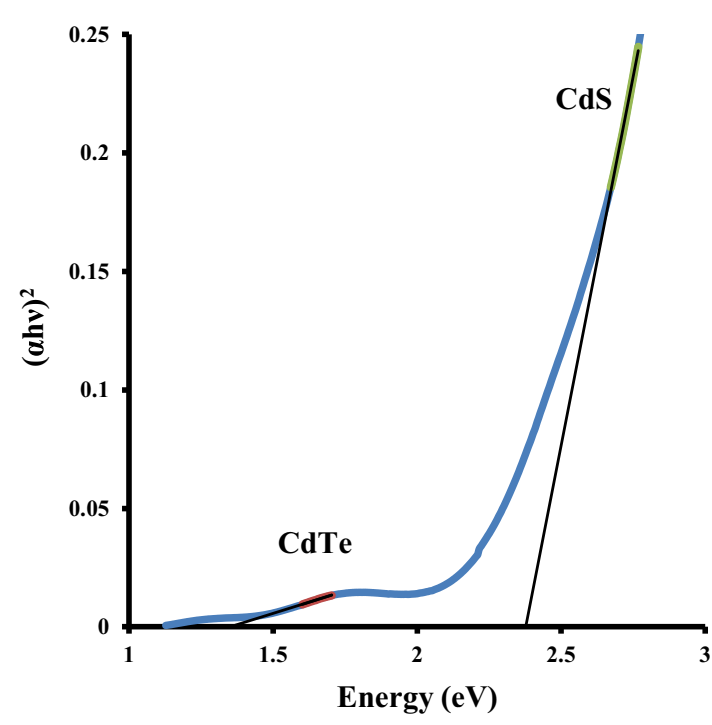

(a)

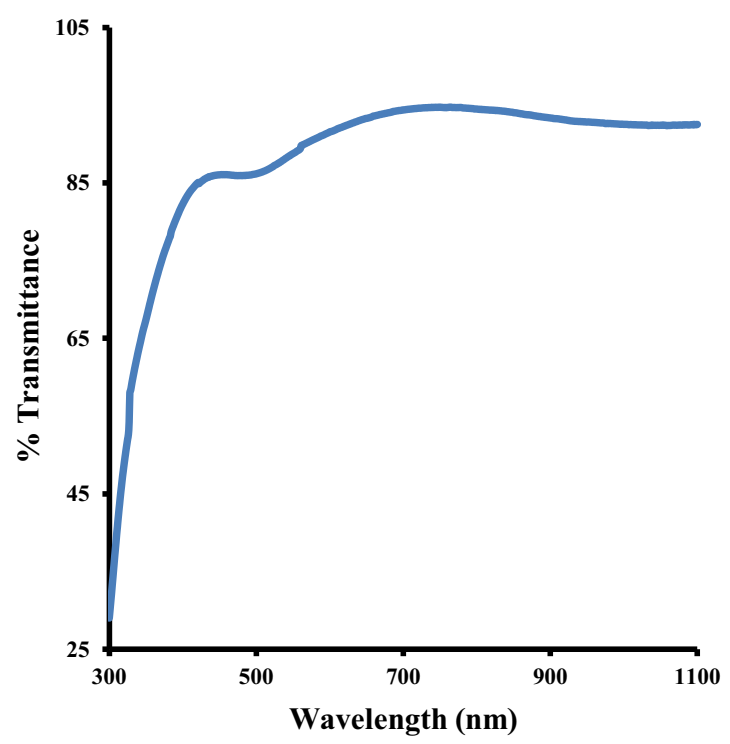

(b)

Fig. 5-(a) UV-Visible absorption spectra of CdTe/CdS thin film. (b) Transmission spectra of solution grown CdS and CdTe film of about $300 \mathrm{~nm}$. 


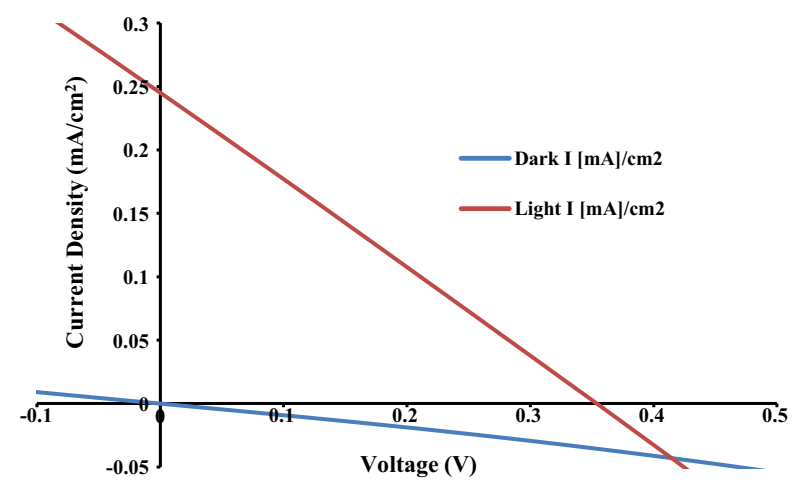

Fig. 6-J-V curve of transparent thin film device.

roughness of each layer was found to be $2.36,42.7$, and $26.1 \mathrm{~nm}$ and that of the cell was $23.9 \mathrm{~nm}$.

\section{Optical Studies}

\section{Absorption}

The optical absorption of the $\mathrm{CdTe} / \mathrm{CdS}$ thin films has been studied in the wavelength range of 300 to $1100 \mathrm{~nm}$ using $\mathrm{UV}$-Visible spectrophotometer. Figure 5a shows the optical band gap of CdTe and CdS thin films determined by plotting $(\alpha h v)^{2}$ verses photon energy $(h v)$ and by extrapolating a straight line portion of the curve to the zero absorption coefficients. The band gaps are in good agreement with those of the reported values. ${ }^{[24,25]}$ The CdS band gap was found to be $2.4 \mathrm{eV}$ and that of CdTe was $1.36 \mathrm{eV}$. The band gap values of CdTe and CdS thin films were calculated using the formula:

$$
\alpha=\left(\frac{A}{h v}\right)(h v-E g)^{n},
$$

where $n=1 / 2$ for direct allowed and forbidden transitions.

\section{Transmission}

Figure $5 \mathrm{~b}$ shows the optical transmission spectra of $\mathrm{CdTe} / \mathrm{CdS}$ thin film. The crystallinity of the film was indicated by the sharpness of the absorption edge (450 to $500 \mathrm{~nm}$ ). 80 pet of transmittance was observed from 300 to $1000 \mathrm{~nm}$ wavelength at room temperature. This property of high transmittance has been achieved by the cost effective solution process (CBD). Such films can be used as window coating and antireflection coatings. ${ }^{[26]}$

\section{IV-Measurements}

The IV-measurements were performed on ITO/CdTe/ $\mathrm{CdS} /$ Aluminum device of large area, i.e., $2.53 \mathrm{~cm}^{2}$. The efficiency of the solar cell has been measured with a Tracer-2 solar simulator under $1000 \mathrm{~W} / \mathrm{m}^{2}$ (1 SUN) incident power and 1.5 AM solar light spectrum. A source meter of 2400 series was used. The measurement system was calibrated through 9 pct efficient crystalline silicon solar cell with known JV parameters. The fill factor and the efficiency were calculated from the relations:

$$
\begin{gathered}
\mathrm{FF}=\frac{I_{\mathrm{max}} V_{\mathrm{max}}}{I_{\mathrm{sc}} V_{\mathrm{oc}}} \\
\eta=\frac{V_{\mathrm{oc}} I_{\mathrm{sc}} \mathrm{FF}}{P_{\text {input }}},
\end{gathered}
$$

where $I_{\max }$ and $V_{\max }$ are the maximum current and maximum voltage measured, $V_{\mathrm{oc}}$ and $I_{\mathrm{sc}}$ are open circuit voltage and short circuit current, and the $P_{\text {input }}$ is the input light intensity. In Figure 6, a current density versus voltage characteristic of the CELL in dark and under illumination $\left(1000 \mathrm{~W} / \mathrm{m}^{2}\right)$ are shown. The parameters of the device are as follows: an efficiency of $0.2 \mathrm{pct}$ with $355.6 \mathrm{mV}$ (open circuit voltage), $0.25 \mathrm{~mA} / \mathrm{cm}^{2}$ (short circuit current density), and a fill factor of 0.25 .

\section{CONCLUSION}

CdTe/CdS thin-film PV has been prepared by chemical bath deposition technique. Both CdTe and CdS thin films prepared with optimized deposition parameters show preferential orientation along (111) direction for CdTe and (101) for CdS. Scanning electron microscopic analysis shows uniform, spherical-shaped grains on the surface of the substrate without any pinholes or cracks. The grain size of CdTe was found to be $270 \mathrm{~nm}$ and $\mathrm{CdS}$ was 15 to $150 \mathrm{~nm}$. The cell thickness and roughness was 600 and $24 \mathrm{~nm}$. In the visible and near infrared regions of electromagnetic spectrum, the $\mathrm{CdTe} / \mathrm{CdS}$ cell exhibited a good transmittance of about 70 to 80 pct. The band gaps of CdTe and CdS were found to be 1.36 and $2.4 \mathrm{eV}$, respectively. Solar cell fabricated from cost effective technique yielded $3.56 \mathrm{e}-01 \mathrm{~V}$ of $V_{\text {oc }}$ and $6.20 \mathrm{e}-04 \mathrm{~A}$ of $I_{\mathrm{sc}}$. Many efforts are going on to improve the film deposition process to increase the $I_{\mathrm{sc}}$ and fill factor.

\section{ACKNOWLEDGMENTS}

The authors thank Prof. K. B. R. Varma (Chairman, Material Research Centre, IISc) and Prof. T. N. Guru Row (Solid State Structural Chemistry Unit, IISc) for their kind help with Atomic force microscopy and XRD characterization. We would also like to thank Mr. Sathyamurthy (Department of Physics, IISc) for his help with Thermal Evaporation and Sputtering.

\section{REFERENCES}

1. BP Statistical Review of World Energy. World's Fuel Consumption. http://www.bp.com (June 2014).

2. Carbon Dioxide Information Analysis Centre (CDIAC). Global Carbon Budget. http://www.globalcarbonbudget.org (2014). 21 September 2014

3. J. Herrero, M.G. Arrez, C.G. An, J. DonAa, M. MartoAnez, A. Chaparro, and R. Bayoan: Thin Solid Film, 2000, vols. 361-362, pp. $28-33$. 
4. M. Hädrich, C. Kraft, H. Metzner, U. Reislöhner, C. Löffler, and A.W. Witthuhn: Phys. Status Solidi C, 2009, vol. 6, pp. 1257-60.

5. U. Madhu, N. Mukherjee, N.R. Bandyopadhyay, and A. Mondal: Indian J. Pure Appl. Phys., 2007, vol. 45, pp. 226-30.

6. D.H. Rose, F.S. Hasoon, R.G. Dhere, D.S. Albin, R.M. Ribelin, X.S. Li, Y. Mahathongdy, T.A. Gessert, and P. Sheldon: Prog. Photovolt. Res. Appl., 1999, vol. 7, pp. 331-40.

7. H. Fardi and F. Buny: Int. J. Photoenergy, 2013, vol. 2013, pp. 1-7.

8. W.F. Mohammed, O. Daoud, and M. Al-Tikriti: Circuits Syst., 2012, vol. 3, pp. 230-37

9. N. Romeo, A. Bosio, R. Tedeschi, A. Romeo, and V. Canevari: Sol. Energy Mater. Sol. Cells, 1999, vol. 58, pp. 209-18.

10. A. Morales-Acevedo: Sol. Energy, 2006, vol. 80, pp. 675-81.

11. T. Gaewdang, N. Wongcharoen, and T. Wongcharoen: Energy Procedia., 2012, vol. 15, pp. 299-304.

12. X. Mathew, J.S. Cruz, D.R. Coronado, A.R. Millan, G.C. Segura, E.R. Morales, O.S. Martınez, C.C. Garcia, and E.P. Landa: Sol. Energy, 2012, vol. 86, pp. 1023-28.

13. N.P. Klochko, N.D. Volkova, M.M. Kharchenko, and V.R. Kopach: Funct. Mater., 2009, vol. 16, pp. 190-91.

14. G.K. Padam and G.L. Malhotra: Mater. Res. Bull., 1989, vol. 24 , pp. 595-601.

15. N.G. Dhere, D.L. Waterhouse, K.B. Sundaram, O. Melendez, N.R. Parikh, and B. Patnaik: J. Mater. Sci. Mater. Electron., 1995, vol. 6 , pp. $52-59$.
16. F. Ouachtari, A. Rmili, S.E.B. Elidrissi, A. Bouaoud, H. Erguig, and P. Elies: J Modern Phys., 2011, vol. 2, pp. 1073-82.

17. S. Sagadevan and K. Pandurangan: Int. J. ChemTech Res., 2014, vol. 7, pp. 3748-3752

18. S.S. Babkair, M.K.M. Al-Turkestani, and A.A. Ansari: Karachi Univ. J. Sci., 2007, vol. 35, pp. 5-10.

19. J.Y. Choi, K.-J. Kim, J.-B. Yoo, and D. Kim: Sol. Energy, 1998, vol. 64, pp. 41-47.

20. L. Gouda, Y.R. Aniruddha, and S.K. Ramasesha: J. Modern Phys., 2012, vol. 3, pp. 1870-77.

21. R. Ortega-Borges and D. Lincot: J Electrochem. Soc., 1993, vol. 140 , pp. 3464-73.

22. S. Deivanayaki, P. Jayamurugan, R. Mariappan, and V. Ponnuswamy: Chalcogenide Lett., 2010, vol. 3, pp. 159-63.

23. H. Khallaf, I.O. Oladeji, G. Chai, and L. Chow: Thin Solid Films, 2008, vol. 516, pp. 7306-12.

24. L. Alejo-Armenta, F. Espinoza-Beltran, C. Alejo-Armenta, C. Vazquez-Lopez, H. Arizpe-Chavez, R. Ramırez-Bon, O. Zelaya-Angel, and J. González-Hernandez: J. Phys. Chem. Solids, 1999, vol. 60, pp. 807-11.

25. F. Lisco, P. Kaminski, A. Abbas, K. Bass, J. Bowers, G. Claudio, M. Losurdo, and J. Walls: Thin Solid Films, 2015, vol. 582, pp. 323-27.

26. B.A. Ezekoye, P. Offor, V.A. Ezekoye, and F.I. Ezema: Int. J. Sci. Res., 2013, vol. 2, pp. 452-56. 